\title{
Direct estimates of emissions from the megacity of Lagos
}

\author{
J. R. Hopkins ${ }^{1}$, M. J. Evans ${ }^{2}$, J. D. Lee ${ }^{1}$, A. C. Lewis ${ }^{1}$, J. H Marsham ${ }^{2}$, J. B. McQuaid ${ }^{2}$, D. J. Parker ${ }^{2}$, D. J. Stewart ${ }^{3}$, \\ C. E. Reeves ${ }^{3}$, and R. M. Purvis ${ }^{1,4}$ \\ ${ }^{1}$ National Centre for Atmospheric Science, University of York, YO10 5DD, UK \\ ${ }^{2}$ School of Earth and Environment, University of Leeds, LS2 9JT, UK \\ ${ }^{3}$ School of Environmental Sciences, University of East Anglia, Norwich, NR4 7TJ, UK \\ ${ }^{4}$ Facility for Airborne Atmospheric Measurement, Cranfield, MK43 0AL, UK
}

Received: 18 January 2009 - Published in Atmos. Chem. Phys. Discuss.: 1 April 2009

Revised: 13 September 2009 - Accepted: 16 October 2009 - Published: 6 November 2009

\begin{abstract}
We report here top-down emissions estimates for an African megacity. A boundary layer circumnavigation of Lagos, Nigeria was completed using the FAAM BAe146 aircraft as part of the AMMA project. These observations together with an inferred boundary layer height allow the flux of pollutants to be calculated. Extrapolation gives annual emissions for $\mathrm{CO}, \mathrm{NO}_{\mathrm{x}}$, and VOCs of $1.44 \mathrm{Tg} \mathrm{yr}^{-1}$, $0.03 \mathrm{Tg} \mathrm{yr}^{-1}$ and $0.37 \mathrm{Tg} \mathrm{yr}^{-1}$ respectively with uncertainties of $+250 /-60 \%$. These inferred emissions are consistent with bottom-up estimates for other developing megacities and are attributed to the evaporation of fuels, mobile combustion and natural gas emissions.
\end{abstract}

\section{Introduction}

The world's "megacities" (populations over 10 million) emit a large fraction of global pollutants (Lawrence et al., 2007). The continued growth of urban populations $\left(2.7 \% \mathrm{yr}^{-1}\right.$ over the last fifty years (Gurjar and Lelieveld, 2005)) has led to an increase in their importance as a pollutant source. Previous projects have investigated Asian (e.g. Guttikunda et al., 2005) and Central American (e.g. Jobson et al., 2004) megacities, but there is little information on African megacities. Here we use observations within the boundary layer of Lagos, Nigeria taken during 2006 as part of the African Monsoon Multidisciplinary Analysis (AMMA, Redelsperger et al., 2006) to infer emissions from the city.

Lagos is Nigeria's commercial capital with $\sim 75 \%$ of the country's industries. It is the second most populated and fastest growing city in Africa. Its population in 2005 was
10.8 million (to rise to 16 million by 2015) making it the world's 17th most populated city (UN, 2005). As with the majority of cities, road transport is thought to be the most significant source of anthropogenic emissions (Baumbach et al., 1995). Often dated technologies and poor emission control strategies lead to substantial uncertainties in emission estimates calculated from vehicle number density statistics. The unreliable electrical supply in Lagos has led to an increased reliance on small-scale diesel powered generators and these potentially present a significant source of emissions in Lagos. The uncontrolled open incineration of waste adds a further very poorly constrained emission source within the city. One of the major thermal power stations in Africa and substantial petrochemical activity is within the city limits.

The African Monsoon Multi-disciplinary Analysis (AMMA) was a 5 year programme to understand the impact of the West African monsoon on both the atmosphere and society of Western Africa (Redelsperger et al., 2006). A major intensive field program occurred in the summer of 2006 with the UK FAAM BAe146 research aircraft being based in the Nigerien capital Niamey.

On the 8 August the FAAM BAe146 flew to the city of Cotonou in Benin. From here the aircraft headed northeastward to arrive over the centre of Lagos. It then descending southward to make a missed approach at Lagos International Airport (with minimum altitude of $20 \mathrm{~m}$ ) and arrived south of the city at $\sim 350 \mathrm{~m}$. The aircraft then made a clockwise circumnavigation of the city at this altitude before climbing over the city and returning to Niamey (see Fig. 1a). 


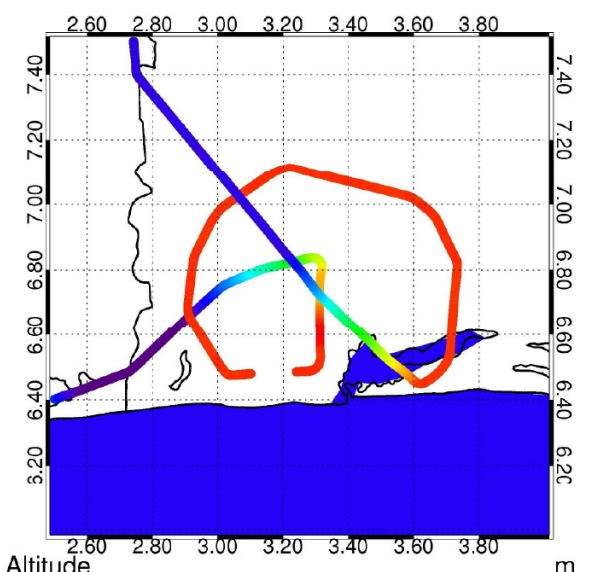

a) $40003600320028002400200016001200800 \quad 400 \quad 0$

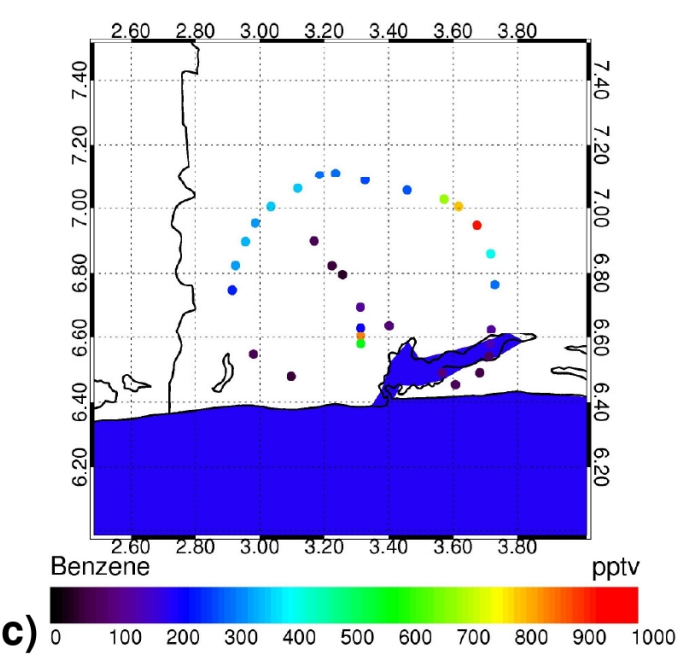

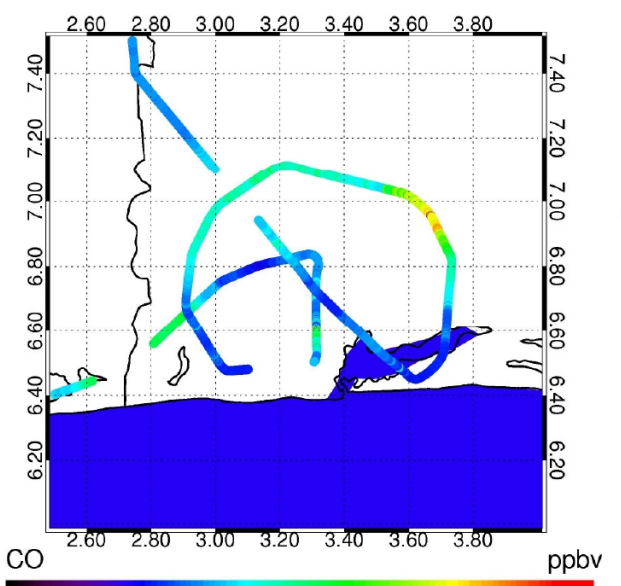

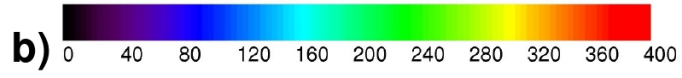

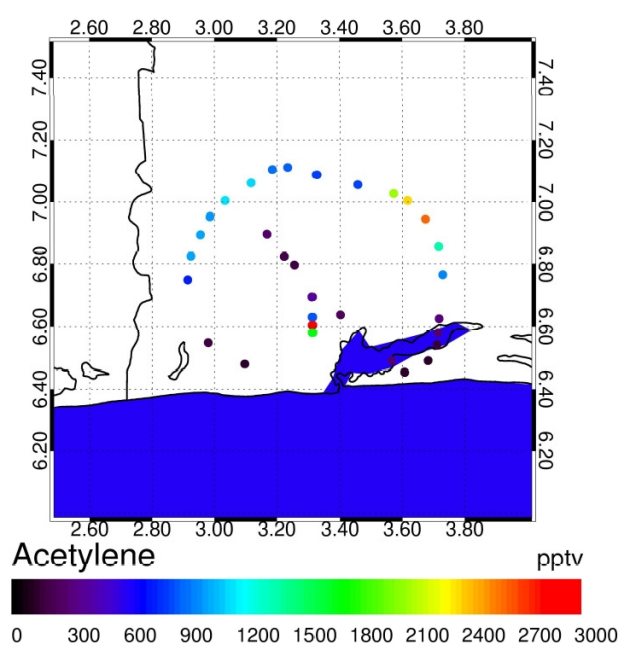

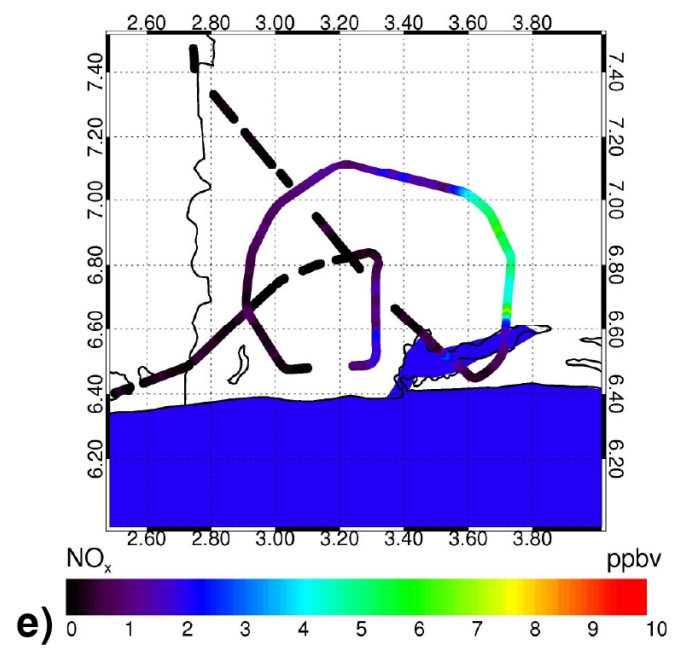

Fig. 1. Observations of altitude (a), CO (b), Benzene (c), Acetylene (d) and TECO $\mathrm{NO}_{\mathrm{x}}(\mathbf{e})$ made during the flight around Lagos. 


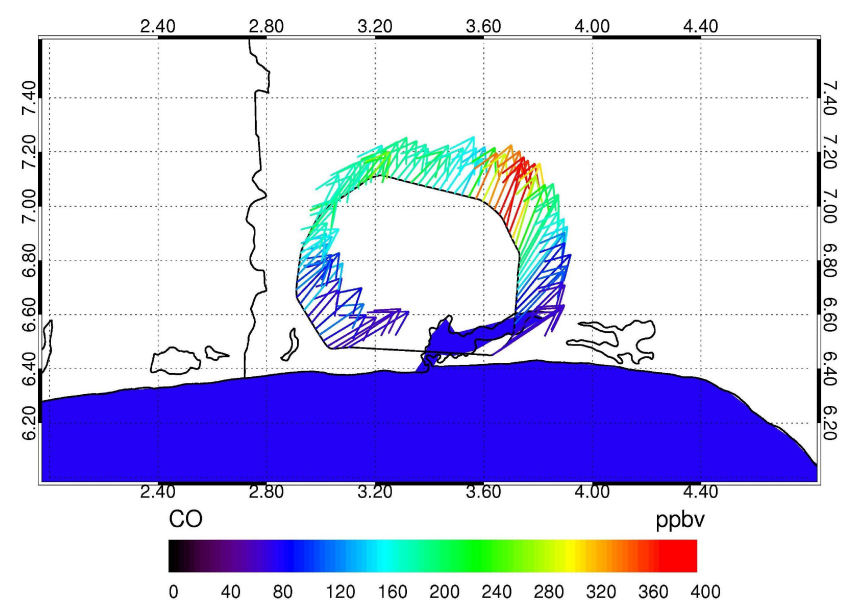

Fig. 2. Wind direction observation from the aircraft coloured by $\mathrm{CO}$ concentration.

\section{Observations}

Measurements of carbon monoxide (CO) were performed using a fast response fluorescence instrument, Aero-Laser 5002 fast CO monitor Gerbig et al. (1999). Oxides of nitrogen $\left(\mathrm{NO}_{\mathrm{x}}\right)$ were measured by two instruments. The first instrument (TECO) measured using a model $42 \mathrm{C}$ trace level $\mathrm{NO}_{\mathrm{x}}$, chemiluminescence analyser (Thermo Environmental Instruments, Hemel Hempstead, UK). The instrument sequentially measured nitric oxide $(\mathrm{NO})$ and total $\mathrm{NO}_{\mathrm{x}}\left(\mathrm{NO}+\mathrm{NO}_{2}\right)$ using a molybdenum catalyst to convert $\mathrm{NO}_{2}$ to $\mathrm{NO}$. Oxides of nitrogen were also measured by the University of East Anglia $\mathrm{NO}_{\mathrm{xy}}$. This measures $\mathrm{NO}$ by its chemiluminescence reaction with $\mathrm{O}_{3}$ and $\mathrm{NO}_{2}$ by photolytic conversion of $\mathrm{NO}_{2}$ to $\mathrm{NO}$ with subsequent measurement of NO. The instrument is described in detail in Brough et al. (2003). Volatile Organic Compounds (VOCs) were measured using silica coated stainless steel canisters (Thames Restek, UK) at approximately 2 min time intervals around the city. Air samples were analysed using a dual channel gas chromatograph with flame ionisation detectors (Hopkins et al., 2003).

Figure $1 \mathrm{~b}-\mathrm{f}$ show the mixing ratio of $\mathrm{CO}$, benzene, acetylene, $\mathrm{NO}_{\mathrm{x}}(\mathrm{TECO})$ and $\mathrm{O}_{3}$ around Lagos. The boundary layer wind originated from the south west (see Fig. 2.) The highest mixing ratios can be observed to the north east of the city. Typical in-plume mixing ratios of $\mathrm{CO}, \mathrm{O}_{\mathrm{x}}$, benzene and acetylene were $\sim 400 \mathrm{ppbv}, 6 \mathrm{ppbv}, 1 \mathrm{ppbv}$ and $1 \mathrm{ppbv}$ respectively.

\section{Calculation of emission fluxes from Lagos}

Given the approximately closed-loop flight track of the aircraft, a uniform boundary layer and no vertical exchange of compound, the horizontal flux of compound out of the Lagos area can be calculated by adding up the components of the

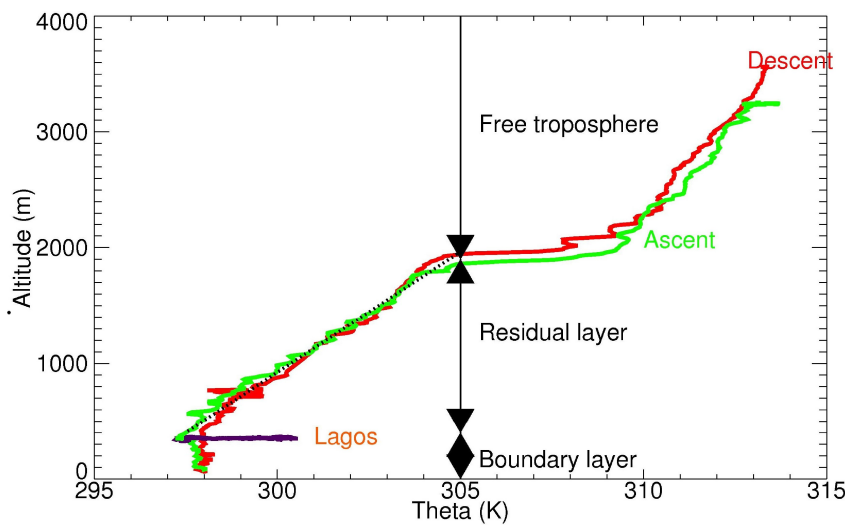

Fig. 3. Profile of $\theta$ during descent into (red), circuit of (blue) and ascent out of (green) Lagos. The marine boundary layer with uniform potential temperature, residual layer and free troposphere are evident. The gradient of $\theta$ within the residual layer is the dashed black line.

observed pollutant mass fluxes perpendicular to the path of the aircraft i.e. by calculating the flux out of the closed loop at each stage around that loop.

$F=\int C(x)(\boldsymbol{v}(x) \cdot \hat{\boldsymbol{V}}(x)) Z(x) d x$

Where $F$ is the flux in $\mathrm{kg} \mathrm{s}^{-1}, C(x)$ is the concentration of the compound in $\mathrm{kg} \mathrm{m}^{-3}$ at position $x(\mathrm{~m})$ along the loop, $v$ is the horizontal wind vector $\left(\mathrm{m} \mathrm{s}^{-1}\right)$ at position $x$ along the loop, $\boldsymbol{V}$ is the aircraft horizontal flight vector $\left(\mathrm{m} \mathrm{s}^{-1}\right)$ at position $x$ along the loop, $Z$ is the boundary layer height (m) at position $x$ along the loop, ${ }^{\wedge}$ represents the unit normal operator, $\cdot$ is the dot product operator.

As $\hat{\boldsymbol{V}}(x)$ represents a unit vector in the horizontal, perpendicular to the path of the aircraft (i.e. a vector pointing out of the loop around Lagos), $v(x) \cdot \hat{\boldsymbol{V}}(x)$ represents the magnitude of the component of the horizontal wind out of that loop. By multiplying this flow out of the loop by the concentration and the boundary layer height, and integrating over the closed loop, the total flux out of the loop is derived. Other than the boundary layer height all these parameters are directly observed.

The vertical mixing within the boundary layer is not instantaneous, leading to the mixing ratio at $350 \mathrm{~m}$ not being wholly indicative of the concentrations throughout the boundary layer. Plumes from large point sources such as power-plants etc may be missed if they pass under or over the aircraft, and if plumes are intercepted they will bias the dataset.

Figure 3 shows the measured profile of potential temperature $(\theta)$ during the descent, circuit and ascent. The profile consists of a marine boundary layer up to $400 \mathrm{~m}$ and a continental residual layer ending at $1900 \mathrm{~m}$. $\theta$ was found to increase away from the coast. The boundary layer height can therefore be expected to have increased away from the coast 


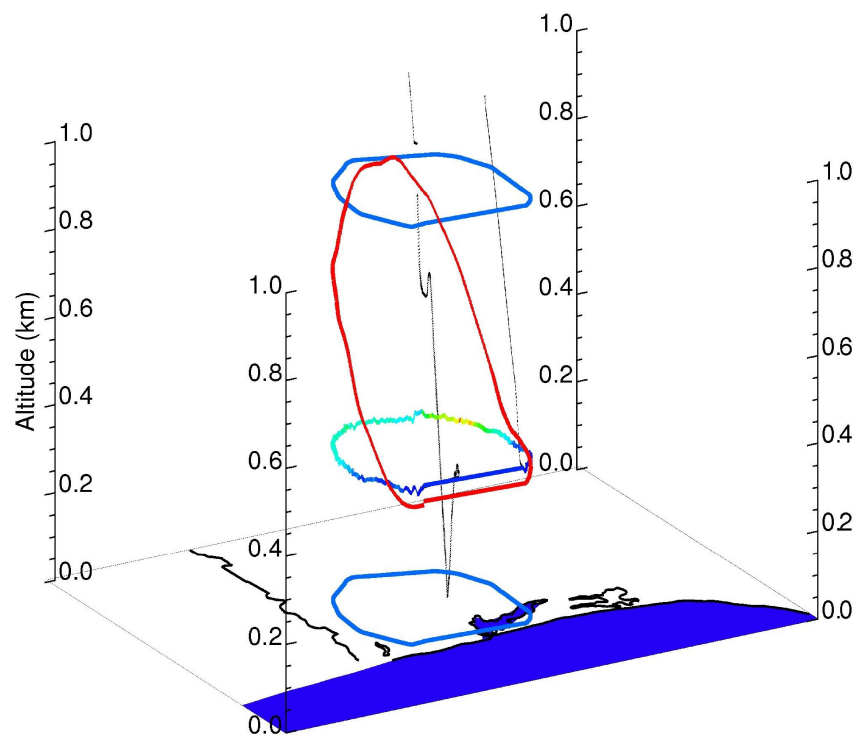

Fig. 4. 3-Dimensional representation of circumnavigation around Lagos. Black line is the aircraft flight track, around the city it is coloured by the $\mathrm{CO}$ mixing ratio; red line is the calculated boundary layer height; the two blue lines are the cylinder considered for the flux calculation.

due to the surface heat fluxes and the resultant entrainment of residual-layer air. The naively estimated boundary layer height at $x(z(x)$ in $\mathrm{m})$ depends only the height of the boundary layer top derived from the profiles $(400 \mathrm{~m}$ respectively, with a potential temperature of 298 K, Fig. 3), the potential temperature observed on the constant altitude loop around the city $\left(\theta_{350 \mathrm{~m}}(x)\right)$ and the increase in $\theta$ with height in the residual layer $\left(214 \mathrm{~m} \mathrm{~K}^{-1}\right.$, the dotted line in Fig. 3). This gives,

$z(x)=400+\left(\theta_{350 \mathrm{~m}}(x)-298\right) \times 214$

However, Carson (1973) shows that the warming of the boundary layer by entrainment of air from the residual layer above will increase the boundary layer height from $z(x)$ (the naively calculated value) to $Z(x)$,

$Z(x)=\frac{1+2 A}{1+A} z(x)$

where $A$ is the entrainment constant, which has a value of roughly 0.3 .

Figure 4 shows the calculated boundary layer height around the Lagos circuit. The boundary layer height has a minimum of $309 \mathrm{~m}$ over the ocean and a maximum of $1100 \mathrm{~m}$ over land furthest from the coast. Over the ocean the aircraft was therefore slightly above $(350 \mathrm{~m})$ the calculated boundary layer. However, due to the lack of sources in this region this does not introduce great uncertainty into the calculation. The variation in boundary layer height over land leads to significant entrainment of air from above. We address this by considering the flux of air into a column around the city with a uniform height of the maximum calculated boundary layer height $\left(Z_{\max }\right)$. We anticipate much lower vertical fluxes out of the top of this volume compared with the fluxes from the top of the volume described by the spatially varying boundary layer height. The horizontal fluxes into this column around the loop are calculated as being a flow within the boundary layer with the observed concentration of compound and a flow from above the boundary layer with a "background" concentration $\left(C_{\text {back }}\right)$ calculated as the value of the 10th percentile of the concentrations around the loop. We assume that there is no difference in the wind vectors in these components. Thus the flux is now calculated to be,

$$
\begin{aligned}
F & =\int C(x)(\boldsymbol{v}(x) \cdot \hat{\boldsymbol{V}}(x)) Z(x) d x \\
& +\int C_{\text {background }}(\boldsymbol{v}(x) \cdot \hat{\boldsymbol{V}}(x))\left(Z_{\max }-Z(x)\right) d x
\end{aligned}
$$

If the emitted species has no loss within the loop, the flux of species from the loop is equivalent to the emission from the city. For some species this is a good assumption. $\mathrm{CO}$ has a lifetime of the order of a month. Thus for the $\sim 1 \mathrm{~h}$ transit across the city, it can be considered an inert tracer. VOC lifetimes range from minutes to months. A large fraction is emitted as NMHC which degrade to produce oxygenated species. Thus by including the oxygenated species in our calculation we mitigate the impact of this VOC loss. Based on calculations from the GEOS-Chem global model of composition and transport (Bey et al., 2001), the inclusions of the observed oxygenates mean that around $92 \%$ of the total carbon emitted should be observed. This is considered in the uncertainty calculation below. $\mathrm{NO}_{\mathrm{x}}$ has a short lifetime in the atmosphere (hours) thus $\mathrm{NO}_{\mathrm{x}}$ exported out of the loop does not reflect all the $\mathrm{NO}_{\mathrm{x}}$ emitted. Observations of speciated $\mathrm{NO}_{\mathrm{y}}$ from other cities suggest that the non $\mathrm{NO}_{\mathrm{x}}$ components of the $\mathrm{NO}_{\mathrm{y}}$ flux are likely to be small $(\sim 20 \%)$ on the timescales important here (e.g. Neuman et al., 2006). Thus the $\mathrm{NO}_{\mathrm{x}}$ observations provide a lower estimate of the emissions of $\mathrm{NO}_{\mathrm{x}}$ and need to be considered in our uncertainty calculation.

No correction for diurnal or hebdomadal variability is made as these parameters are not known for a city of this type. Studies in countries such as the UK, show that the ratio between maximum and minimum hourly emission are of the order 5, 3.5 and 4 for $\mathrm{CO}$, VOCs and $\mathrm{NO}_{\mathrm{x}}$ respectively, variations between weekday and weekend are of the order $30 \%$, and annual variation of the order of $30 \%$ (Jenkin et al., 2000). Given the observations were made in the midafternoon (3 p.m. local time) on a Tuesday in the tropics (where annual temperature variations are smaller) we probably overestimate the actual annual emission by a factor of around 2-3 depending upon the species. Given no comparable information for Lagos, we do not adjust our value for these variations. 
Table 1. Annualised emissions fluxes from Lagos calculated from this and other studies together with emissions from other mega-cities on both a total and per capita basis.

\begin{tabular}{|c|c|c|c|c|c|c|}
\hline Total Emissions & $\begin{array}{l}\text { Lagos }^{\mathrm{a}} \\
\operatorname{Tg}^{-1}{ }^{-1}\end{array}$ & $\begin{array}{l}\text { Lagos }^{b} \\
\operatorname{Tg~yr}^{-1}\end{array}$ & $\begin{array}{l}\text { Beijing } \\
\operatorname{Tg~yr}^{-1}\end{array}$ & $\begin{array}{c}\text { Calcutta }^{\mathrm{c}} \\
\mathrm{Tg} \mathrm{yr}^{-1}\end{array}$ & $\begin{array}{l}\text { Tokyo }^{\mathrm{c}} \\
\text { Tg yr }^{-1}\end{array}$ & $\begin{array}{l}\text { Londond }^{\mathrm{d}} \\
\operatorname{Tg~yr}^{-1}\end{array}$ \\
\hline $\mathrm{CO}$ & 1.44 & 0.81 & 1.23 & 0.63 & 0.46 & 0.13 \\
\hline Alkanes & 0.1356 & & & & & \\
\hline Alkenes & 0.0263 & & & & & \\
\hline Alkynes & 0.0159 & & & & & \\
\hline Aromatics & 0.0723 & & & & & \\
\hline Oxygenates & 0.1196 & & & & & \\
\hline Total VOC & 0.37 & 0.73 & 0.23 & 0.23 & 0.20 & 0.08 \\
\hline $\mathrm{NO}_{\mathrm{x}}^{\mathrm{e}}$ & 0.03 & 0.97 & 0.04 & 0.02 & 0.05 & 0.08 \\
\hline City Population $(2005)^{\mathrm{f}}$ & 10886000 & 10886000 & 14227000 & 35197000 & 8505000 & 8567000 \\
\hline Personal emissions & $\mathrm{kg} \mathrm{per}^{-1} \mathrm{yr}^{-1}$ & $\mathrm{~kg} \mathrm{per}^{-1} \mathrm{yr}^{-1}$ & $\mathrm{~kg} \mathrm{per}^{-1} \mathrm{yr}^{-1}$ & $\mathrm{~kg} \mathrm{per}^{-1} \mathrm{yr}^{-1}$ & $\mathrm{~kg} \mathrm{per}^{-1} \mathrm{yr}^{-1}$ & $\mathrm{~kg} \mathrm{per}^{-1} \mathrm{yr}^{-1}$ \\
\hline $\mathrm{CO}$ & 132 & 74 & 86 & 18 & 54 & 15 \\
\hline VOC & 34 & 67 & 16 & 7 & 23 & 9 \\
\hline $\mathrm{NO}_{\mathrm{x}}$ & 3.2 & 89.1 & 2.5 & 0.5 & 6.3 & 9.3 \\
\hline
\end{tabular}

a This study

b Oketola et al. (2007)

c Guttikunda et al. (2005)

d Mattai et al. (2003)

e This is the mean of the TECO $\mathrm{NO}_{\mathrm{x}}$ and UEA $\mathrm{NO}_{\mathrm{xy}}$ instruments

${ }^{\mathrm{f}} \mathrm{UN}(2005)$

\section{Results}

Table 1 presents the calculated values annual emissions together with literature values for the emissions from Lagos (Oketola et al., 2007), two developing Asian mega-cities (Guttikunda et al., 2000) and two developed mega-cities (Guttikunda et al., 2005; Mattai et al., 2003).

Our CO estimate $\left(1.44 \mathrm{Tg} \mathrm{yr}^{-1}\right)$ is higher than that calculated by Oketola et al. (2007) $\left(0.81 \mathrm{Tg} \mathrm{yr}^{-1}\right)$ and the summary of other estimations given for Lagos by Butler et al. (2008) (0.771 to $\left.1.006 \mathrm{Tg} \mathrm{yr}^{1}\right)$. Given the uncertainties in our estimates (see next section) and in the bottom up estimates (quotes as being for $\mathrm{CO} \sim 68 \%$ for $95 \%$ confidence by Streets et al. (2006) for Asia) the differences are within the combined uncertainties. A major source of the low bias in the bottom up estimates may be the population of Lagos. The local government contests the results of the national census claiming a significant undercount (17 rather than 9 million) of its population (Makama, 2007). This would be consistent with our higher top-down estimate, however there may be economic activity related reasons (for example the petrochemical works and power stations within the loop) to explain this difference as well.

Our VOC estimate $\left(0.37 \mathrm{Tg} \mathrm{yr}^{-1}\right)$ is lower than that calculated by Oketola et al. (2007) $\left(0.73 \mathrm{Tg} \mathrm{yr}^{-1}\right)$, however compared to the other cities the value appears high. Although these bottom-up assessments do not quote suitable uncertain-

ties for VOC emissions, those calculated from Asian cities are $\sim 130 \%$ (Streets et al., 2003). Although significant differences exist between the bottom-up and top-down approaches they are within the range of uncertainties especially given the uncertainty in the population. The higher per person values calculated here compared to other mega-cities may reflect the role of the petrochemical industry for the economy of Lagos.

The $\mathrm{NO}_{\mathrm{x}}$ emissions $\left(0.03 \mathrm{Tg} \mathrm{yr}^{-1}\right)$ derived are more than an order of magnitude smaller than those quoted by Oketola et al. (2007) $\left(0.97 \mathrm{Tg} \mathrm{yr}^{-1}\right)$. Oketola et al. (2007) suggest a per capita $\mathrm{NO}_{\mathrm{x}}$ emission an order of magnitude higher than highly developed cities such as London and Tokyo. Large $\mathrm{NO}_{\mathrm{x}}$ emissions occur in high temperature combustion processes typical of heavily trafficked developed economies, thus the high value of Oketola et al. (2007) appears inconsistent with previous analyses of the sources of urban $\mathrm{NO}_{\mathrm{x}}$. Our emissions are consistent with other studies, especially when considered per capita.

In general our top-down emissions are consistent with the state of understanding of emissions as represented by the bottom up estimates. Significant differences exist, however, given the uncertainties in approaches they are not in tension (other than for the $\mathrm{NO}_{\mathrm{x}}$ estimate of Oketola et al. (2007)). 


\section{Uncertainties}

The calculation of emissions in this paper has many uncertainties and assumptions. If we assume the basic assumptions (as manifest by the equation used to derive the emissions) as valid we can investigate the known uncertainties through Monte-Carlo methods. The emissions calculation was performed 10000 times varying the input parameters (concentrations, temperatures and wind velocities) within the range given by the instrument scientists for both bias and noise of the instrument. This led to uncertainties of $7 \%, 20 \%$ and $10 \%$ for the $\mathrm{CO}, \mathrm{NO}_{\mathrm{x}}$ and $\mathrm{VOC}$ emissions respectively. The impact of chemical processing within the loop is discussed earlier and adds an uncertainty of $0,20 \%$ and $8 \%$ to the $\mathrm{CO}$, $\mathrm{NO}_{\mathrm{x}}$ and VOC emissions estimates. Uncertainties about the seasonal, diurnal and hebdomadal variation leads to variations of order $+200 /-50 \%$ on the emissions.

During the profile over the airport the $\mathrm{CO}$ concentration at $350 \mathrm{~m}$ was $94 \mathrm{ppbv}$, however, the mean $\mathrm{CO}$ concentration within the profile was $131 \mathrm{ppbv}$ due to a surface enhancement. This enhancement may reflect enhanced economic activity at the airport but may also reflect a lack of efficient mixing within the boundary layer. Based on the observed profiles over the airport we add uncertainties of $30 \%, 150 \%$ and $45 \%$ to the uncertainties of the $\mathrm{CO}, \mathrm{NO}_{\mathrm{x}}$ and VOC emissions. The combined impact of these uncertainties leads to over-all uncertainties of $200 \%, 250 \%$ and $205 \%$ for the $\mathrm{CO}, \mathrm{NO}_{\mathrm{x}}$ and VOC emissions respectively. We select the largest (250\%) of these to describe all of our emissions - thus our emissions lay between $40 \%$ to $350 \%$ of the stated value $(+250 /-60 \%)$. Most of this uncertainty lies in the uncertainty of converting a semi-instantaneous flux to an annual average.

\section{Sources of emission within Lagos}

The range of sources within the city is reflected in the complex relationships between species. For example the maxima in $\mathrm{CO}$, benzene, acetylene and $\mathrm{NO}_{\mathrm{x}}$ all lie in different locations around the loop (see Fig. 1b-e). The VOC composition reveals a dominant signature from mono-aromatic compounds and linear and branched chain alkanes; such species are associated primarily with evaporative sources from gasoline and solvent use. The covariance in 1,3 butadiene, $\mathrm{CO}$ and $\mathrm{NO}_{\mathrm{x}}$, is strongly indicative of a major vehicle combustion emission within the city. Finally substantial downwind enhancement in ethane suggests fugitive natural gas leakage. In the absence of a domestic distribution network within Lagos, this may be associated with city electricity production.

\section{Conclusions}

The combination of a coastal location and an on-shore wind makes Lagos an ideal candidate city for emissions estimates via "closed-loop" observations. Annual emissions fluxes for
$\mathrm{NO}_{\mathrm{x}}$ were found to be comparable to those calculated for selected other megacities, whereas VOC and $\mathrm{CO}$ were amongst the highest. Given these observations the predicted future population growth within Lagos will no doubt serve to position Lagos as one of the most polluting cities in the world unless adequate policy measures are implemented.

Acknowledgements. This work was specifically supported by the United Kingdom Natural Environment Research Council via grant NE/B505570/1 and the European Union via Framework Six grant 004089. Based on a French initiative, AMMA was built by an international scientific group and is funded by a large number of agencies, especially from France, the UK, the USA and Africa. It has been the beneficiary of a major financial contribution from the European Community's Sixth Framework Research programme. Detailed information on scientific coordination and funding is available on the AMMA international web site http://www.amma-international.org.

Edited by: P. Formenti

\section{References}

Baumbach, G., Vogt, U., Hein, K. R. G., Oluwole, A. F., Ogunsola, O. J., Olaniyi, H. B., and Akeredolu, F. A.: Air pollution in a large tropical city with a high traffic density - results of measurements in Lagos, Nigeria, Sci. Total. Environ., 169(1-3), 25-31, 1995.

Bey I., Jacob, D. J., Yantosca, R. M., Logan, J. A., Field, B., Fiore, A. M., Li, Q., Liu, H., Mickley, L. J., and Schultz, M.:Global modeling of tropospheric chemistry with assimilated meteorology: Model description and evaluation, J. Geophys. Res., 106, 23073-23096, 2001.

Brough, N., Reeves, C. E., Penkett, S. A., Stewart, D. J., Dewey, K., Kent, J., Barjat, H., Monks, P. S., Ziereis, H., Stock, P., Huntrieser, H., and Schlager, H.: Intercomparison of aircraft instruments on board the C-130 and Falcon 20 over southern Germany during EXPORT 2000, Atmos. Chem. Phys., 3, 21272138, 2003, http://www.atmos-chem-phys.net/3/2127/2003/.

Butler, T. M., Lawrence, M. G., Gurjar, B. R., van Aardenne, J., Schultz, M., and Leliveld, J.: The representation of emission from megacities in global emissions inventories, Atmos. Environ., 42, 703-719, 2008.

Carson, D. J.: Development of a dry inversion-capped convectively unstable boundary layer, Q. J. R. Met. Soc., 99, 421, 450-467, 1973.

Gerbig, C., Schmitgen, S. Kley, D., Volz-Thomas, A., Dewey, K., and Haaks,D.: An improved fast-response vacuum-UV resonance fluorescence CO instrument, J. Geophys. Res., 104(D1), 1699-1704, 1999.

Gurjar, B. R. and Lelieveld, J.: New Directions: Megacities and global change, Atmos. Environ., 39(2), 391-393, 2005.

Guttikunda, S. K., Tang, Y. H., Carmichael, G. R., Kurata, G., Pan, L., Streets, D. G., Woo, J. H., Thongboonchoo, N., and Fried, A.: Impacts of Asian megacity emissions on regional air quality during spring 2001, J. Geophys. Res., 110(D20), D20301, 2005.

Hopkins, J. R., Lewis, A. C., and Read, K. A.: A two-column method for long-term monitoring of non-methane hydrocar- 
bons (NMHCs) and oxygenated volatile organic compounds (oVOCs), J. Environ. Monit., 5(1), 8-13, 2003.

Jenkin, M. E, Murrells, T. P., and Passant, N. R.: The Temporal Dependence of Ozone Precursor Emissions: Estimation and Application, Report to the UK Dept., Energy Trade and the Regions, Air and Environmental Quality Division, AEAT/R/ENV/0355, available from: http://www.naei.org.uk/reports.php, 2000.

Jobson, B. T., Berkowitz, C. M., Kuster, W. C., Goldan, P. D., Williams, E. J., Fesenfeld, F. C., Apel, E. C., Karl, T., Lonneman, W. A., and Riemer D.: Hydrocarbon source signatures in Houston, Texas: Influence of the petrochemical industry, J. Geophys. Res., 109(D24), D24305, 2004.

Lawrence, M. G., Butler, T. M., Steinkamp, J., Gurjar, B. R., and Lelieveld, J.: Regional pollution potentials of megacities and other major population centers, Atmos. Chem. Phys., 7, 39693987, 2007,

http://www.atmos-chem-phys.net/7/3969/2007/.

Makama, S. D.: Population and Development Review, Vol. 33, 1, 206-210, 2007.

Mattai, J. and Hutchinson, D.: London Atmospheric Emissions Inventory 2003, Second Report, Greater London Authority, City Hall, London, SE1 2AA, 2006.

Neuman, J. A., Parrish, D. D., Trainer, M., Ryerson, T. B., Holloway, J. S., Nowak, J. B., Swanson, A., Flocke, F., Roberts, J. M., Brown, S. S., Stark, H., Sommariva, R., Stohl, A., Peltier, R., Weber, R., Wollny, A. G., Sueper, D. T., Hubler, G., Fehsenfeld, F. C.: Reactive nitrogen transport and photochemistry in urban plumes over the North Atlantic Ocean, J. Geophys. Res., 111, D23S54, doi:10.1029/2005JD007010, 2006.
Oketola, A. A. and Osibanjo, O.: Estimating sectoral pollution load in Lagos by Industrial Pollution Projection System (IPPS), Sci. Total. Environ., 377, 125-141, 2007.

Otter, L., Guenther, A., Wiedinmyer, C., Fleming, G., Harley, P., and Greenberg, J. P: Spatial and temporal variations in biogenic volatile organic compound emissions for Africa south of the equator, J. Geophys. Res., 108(D13), 8505, doi:10.1029/2002JD002609, 2003.

Redelsperger, J.-L., Thorncroft, C. D., Diedhiou, A., Lebel, T., Parker, D. J., and Polcher, J.: African Monsoon Multidisciplinary Analysis: An International Research Project and Field Campaign, Bull. Am. Met. Soc. 87, 1739-1746, 2006.

Streets, D. G., Bond, T. C., Carmichael, G. R., Fernandes, S. D., Fu, Q., He, D., Klimont, Z., Nelson S. M., Tsai, N. Y., Wang, M. Q., Woo, J. H., Yarber, K. F.: An inventory of gaseous and primary aerosol emissions in Asia in the year 2000, J. Geophys. Res., 108(D21), 8809, doi:10.1029/2002JD003093, 2003.

Streets, D. G., Zhang, Q., Wang, L., He, K., Hao, J., Wu, Y., Tang, Y., and Carmichael, G. R.: Revisiting China's CO emissions after the Transport and Chemical Evolution over the Pacific (TRACE-P) mission: Synthesis of inventories, atmospheric modeling, and observations, J. Geophys. Res., 111, D14306, doi:10.1029/2006JD007118, 2006.

UN: World Population Prospects: The 2005 Revision, Vol. I, Comprehensive Tables (United Nations publication, Sales No. E.05.XIII.5), ESA/P/WP/2005, www.un.org/esa/population/ publications/WUP2005/2005wup.htm, 2005. 